\title{
Long non-coding RNAs in renal cell carcinoma: A systematic review and clinical implications
}

\author{
Ming Li ${ }^{1}$, Ying Wang ${ }^{2,3}$, Liang Cheng ${ }^{4}$, Wanting Niu ${ }^{5}$, Guoan Zhao ${ }^{6}$, Jithin K. Raju7, \\ Jun Huo ${ }^{1}$, Bin Wu ${ }^{1}$, Bo Yin ${ }^{1}$, Yongsheng Song ${ }^{1}$ and Renge $\mathrm{Bu}^{1}$ \\ ${ }^{1}$ Department of Urology, Shengjing Hospital of China Medical University, Shenyang, Liaoning 110004, P.R. China \\ ${ }^{2}$ Department of Nuclear Medicine, The First Affiliated Hospital of China Medical University, Shenyang, Liaoning 110001, P.R. \\ China \\ ${ }^{3}$ Department of Radiology, Massachusetts General Hospital, Harvard Medical School, Boston, Massachusetts 02114, USA \\ ${ }^{4}$ Department of Pathology and Laboratory Medicine, Indiana University School of Medicine, Indianapolis, IN 46202, USA \\ ${ }^{5}$ Department of Orthopedics, Brigham and Women's Hospital, VA Boston Healthcare System, Harvard Medical School, Boston, \\ Massachusetts 02115, USA \\ ${ }^{6}$ School of Network Education, Beijing University of Posts and Telecommunications, Hebei, Beijing 100088, P.R. China \\ ${ }^{7}$ Department of Clinical Medicine, China Medical University, Shenyang, Liaoning 110122, P.R. China \\ Correspondence to: Renge Bu, email: burg@sj-hospital.org \\ Keywords: renal cell carcinoma, IncRNA, diagnosis, prognosis, therapy
}

Received: November 18, $2016 \quad$ Accepted: March 20, $2017 \quad$ Published: April 12, 2017

Copyright: Li et al. This is an open-access article distributed under the terms of the Creative Commons Attribution License (CC-BY), which permits unrestricted use, distribution, and reproduction in any medium, provided the original author and source are credited.

\section{ABSTRACT}

Renal cell carcinoma is one of the most common malignancy in adults, its prognosis is poor in an advanced stage and early detection is difficult due to the lack of molecular biomarkers. The identification of novel biomarkers for RCC is an urgent and meaningful project. Long non-coding RNA (IncRNA) is transcribed from genomic regions with a minimum length of $\mathbf{2 0 0}$ bases and limited protein-coding potential. Recently, IncRNAs have been greatly studied in a variety of cancer types. They participate in a wide variety of biological processes including cancer biology. In this review, we provide a new insight of the profiling of IncRNAs in RCC and their roles in renal carcinogenesis, with an emphasize on their potential in diagnosis, prognosis and potential roles in RCC therapy.

\section{INTRODUCTION}

Renal cell carcinoma (RCC) is one of the most common urinary tract malignancies in adults. In 2016, 62,700 newly identified cases and 14240 deaths from kidney and renal pelvis, cancer was estimated to occur in the United States [1]. With mortality at about $3 \%$ of all cases and the rate continues to remain very high [1]. In China, an estimated of $66.8 \%$ new cases and $23.4 \%$ deaths from renal cancer occurred in 2015 [2]. The most prevalent RCC histological subtype is clear cell RCC (ccRCC), which accounts for $70 \%$ of RCC, followed by papillary RCC (pRCC) and chromophobe RCC (chRCC) (with a prevalence of 10 and $5 \%$, respectively) [3]. In 2016, world health organization (WHO) modified the classification of RCC and added several newly recognized renal tumors [4].
The tumorigenesis of RCC is extremely complex, not only entailing genetic changes but also including dysregulation of epigenetic pathways [5]. Many wellknown key signal transduction pathways such as VHL/ HIF, PI3K/Akt/mTOR, Raf/MAPK/ERK Jak/Stat, and Wnt- $\beta$-catenin pathway have been demonstrated to be involved in the pathogenesis and development of RCC [6-10]. Although great insight into the epigenetics of RCC has been made, for instance, DNA methylation [11], histone modification [12], as well as noncoding RNA [13]. But the underlying epigenetic mechanisms still need to be further studied. Currently, there are no specific and effective molecular biomarkers for RCC. Thus, the identification of novel biomarkers for RCC is extremely urgent and maybe further serve as therapeutic targets for the treatment. 
It is estimated that $80 \%$ of the human genome is transcribed. But only $1-2 \%$ of the whole genome is proteinencoded. Remaining non-coding portions of the genome transcription products are non-coding RNAs, they are different in biogenesis, properties and functions [14, 15]. There are many famous non-cording RNAs, microRNAs (miRNAs), small interfering RNAs (siRNAs), transfer RNAs (tRNAs), ribosomal RNAs (rRNAs), small nuclear RNAs (snRNAs), small nucleolar RNAs (snoRNAs), all of which play critical roles in mammalian cells [16]. Most of them are transcribed by RNA polymerase II; some are transcribed by RNA polymerase III [16]. They participate in the epigenetic regulation of other molecules, binding to DNAs, proteins and/or other RNAs $[17,18]$. Recently, a newly discovered type of long non-coding RNA molecules (lncRNAs), which are over 200 nucleotides have been greatly studied in multiple diseases and biology [19]. The functions and mechanisms of lncRNAs in mammalian cells are described in detail in Figure 1 [20-32]. Moreover, lncRNAs are involved in cancer biology and have been listed into one of the hallmarks of cancer [33, 34]. They are associated with oncogenesis and may serve as promising a new type of biomarkers for tumor diagnosis, prognosis, even in targeted gene therapy $[19,35,36]$.

LncRNAs have been found involved in tumorigenesis, disease progression and metastasis of RCC. They function as oncogenes or tumor suppress genes and regulate multiple biologic or pathological processes, which are shown in Figure 2. But the underlying mechanisms still need to be further explored. In this systematic review, we focus on the expression profile of IncRNAs in RCC, with emphasize on the roles of oncogenesis, diagnosis, progression, prognosis and the potential of application in RCC therapy.

\section{LNCRNAS IN RCC}

\section{Aberrant expression profiling of Incrnas in RCC}

Many studies about lncRNAs expression profiling have been carried out in RCC. The determination of their interaction with other molecules and functional analysis is also booming in recent years. The most popular methods for the study of lncRNAs expression profiles of RCC are microarray assay and ChIP-Seq in small sample trials [37-43]. If certain lncRNAs are found to be obviously dysregulated, following qPCR experiments to demonstrate the significance in large scale samples are preferred, some of these significant dysregulated lncRNAs confirmed by qPCR may even serve as a diagnostic or prognostic biomarkers. [37-39]. A couple of recent studies found that hundreds of thousands of lncRNAs were aberrantly expressed in RCC tissue compared with adjacent nontumor tissue through genome wide assay [37-43]. We summarized these studies in Table 1 in detail [37-43]. In addition, lncRNAs deregulated in RCC are shown in Table 2A and Table 2B; the functions, targeted genes/signaling, and the mechanisms involved are also indicated [44-67].

The lncRNAs aberrantly expressed maybe participate in the carcinogenesis and progression of RCC. In addition, lncRNA profiling and the research results indicate that lncRNAs may be suitable for diagnostic, even in the prediction of prognostic purposes for RCC. A deeper study of

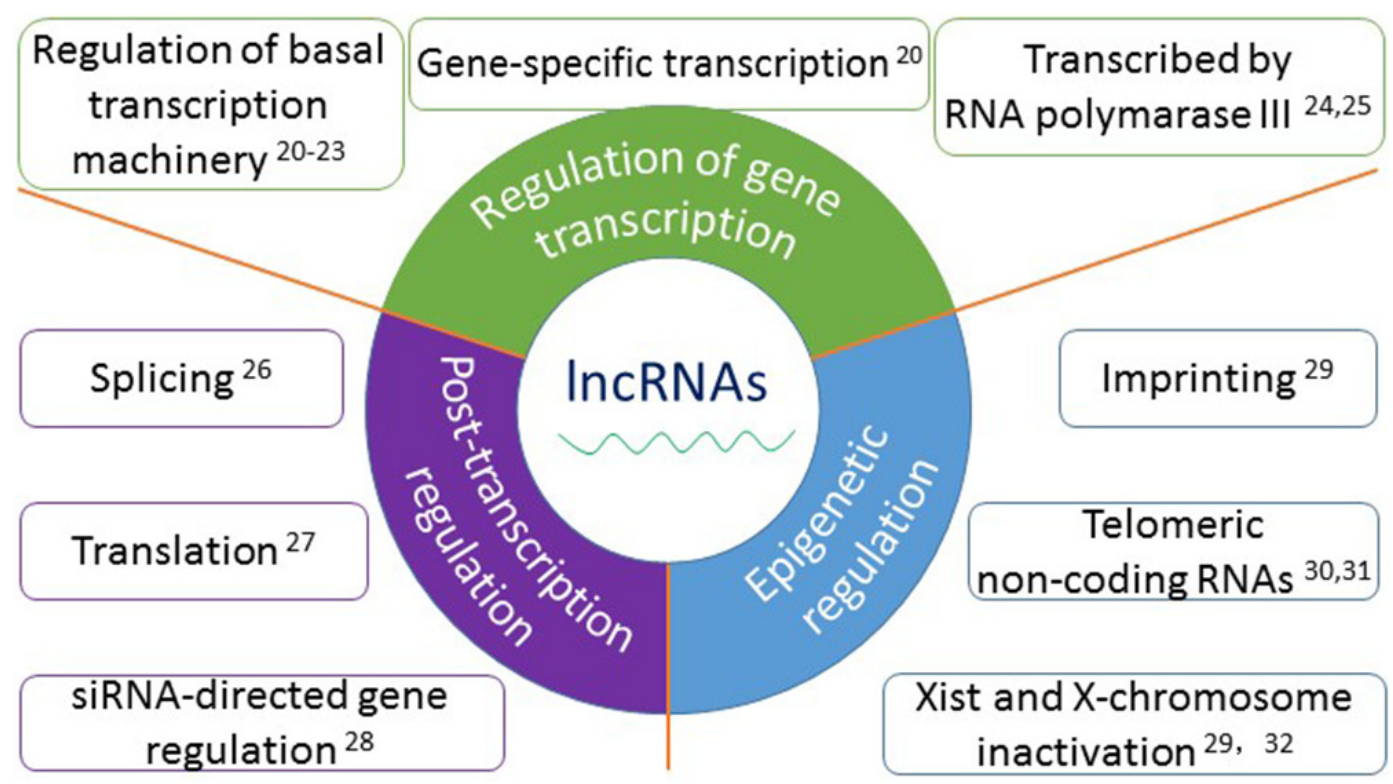

Figure 1: The functions and mechanisms of long non-coding RNAs. Accumulated evidence show that lncRNAs play important roles in a wide variety of biological processes, mainly in three aspects: 1. In the regulation of gene transcription, such as regulation of basal transcription machinery, gene-specific transcription and transcribed by RNA polymerase III; 2. In post-transcriptional regulation, such as splicing, translation, and siRNA-directed gene regulation; 3. In epigenetic regulation, such as imprinting, telomeric non-coding RNAs and Xist and X-chromosome inactivation. 
these lncRNAs may pave a way for a further understanding in the basic science of RCC. Despite numerous efforts have been made, the mechanisms of lncRNAs, such as the transduction pathways and regulation functions of lncRNAs in RCC still need to be explored in further detail.

\section{Diagnosis and biomarkers}

Many studies of determining aberrant lncRNAs expression for diagnostic purpose and the identification of novel deregulated lncRNAs as biomarkers for RCC have been carried out. A recent study found that the expression level of CYP4A22-2/3 can discriminate ccRCCs from normal kidney tissues [68]. In another study, IncRNAATB was found to be elevated in metastatic RCC patients, and higher expression of lncRNA-ATB correlated with disease progression and a more invasive feature, as well as metastasis [48]. In addition, RCCRT1 has a significant relationship with clinicopathologic features of ccRCC patients, including the size of tumor, the pathological staging and tumor grade [49], it is also associated with metastasis of lymph node as well as distal metastasis in ccRCC [49]. Moreover, TCL6 expression was an independent predictor of ccRCC aggressiveness and was negatively correlated with the T, N, M, and TNM stage [65].

The technique for detection and measurement of specific serum lncRNAs has become feasible, which provides a new method without invasiveness for the identification of new biomarker for cancer. Recent studies found that serum lncRNAs are useful for the diagnosis of multiple types of cancer, such as bladder cancer [69], liver cancer [70], cervical cancer [71], gastric cancer [72], colorectal cancer $[73,74]$ and breast cancer $[75]$ etc, these serum lncRNAs may even serve as prognostic biomarkers $[69,72,74]$. Serum lncRNAs in RCC patients are also

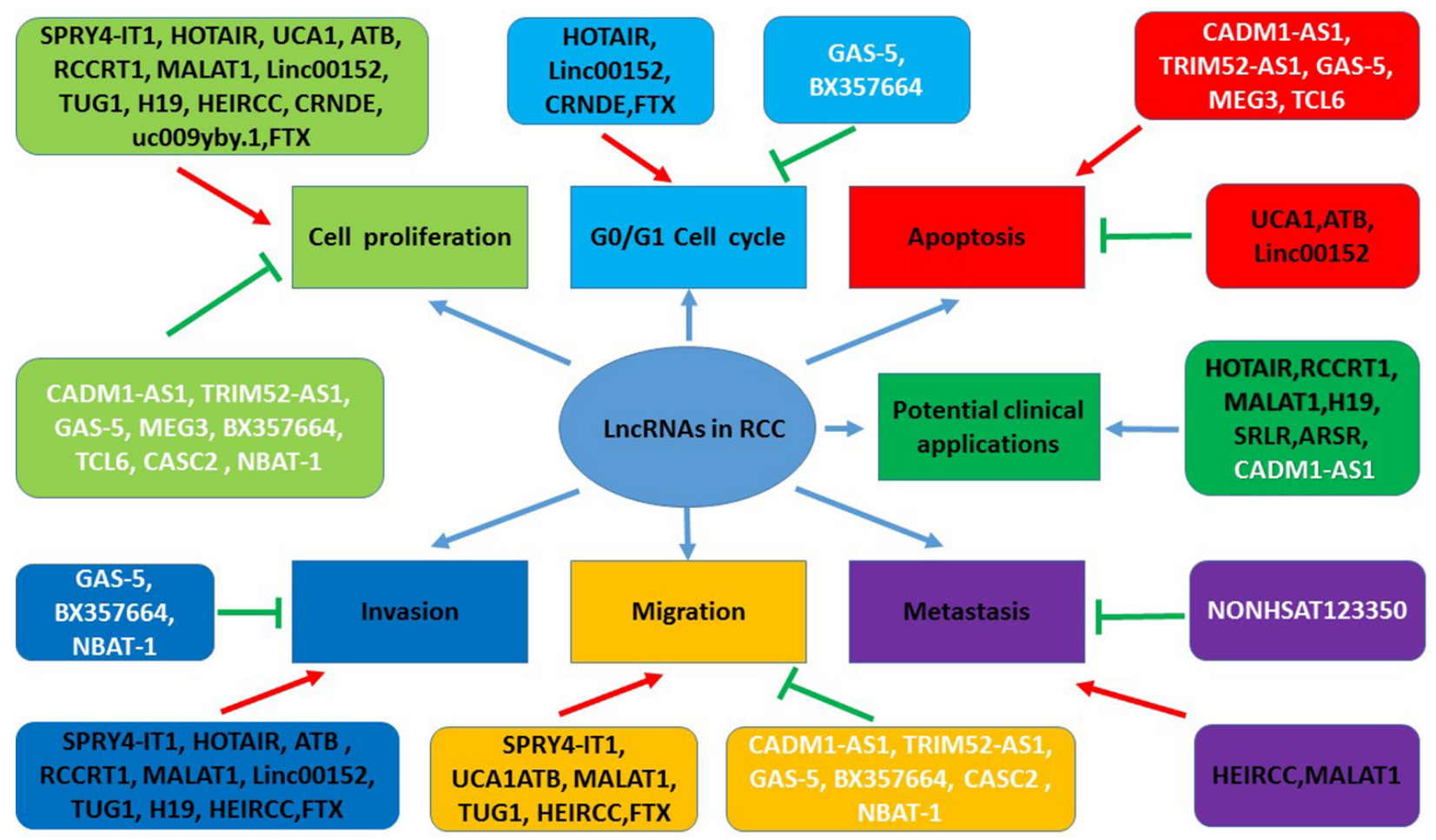

Figure 2: The functions of IncRNAs in pathogenesis and potential clinical applications in RCC. LncRNAs play multiple functions in the context of RCC, including regulating cell proliferation, cell cycle, apoptosis, invasion, migration, and metastasis in the forms of oncogenes or tumor suppressor genes. Some lncRNAs maybe serve as therapeutic targets and have the potential of the clinical application. Red arrows indicate promoted signaling pathways. Green arrows indicate inhibited signaling pathways. LncRNAs in black font indicate oncogenes. LncRNAs in white font indicate tumor suppressor genes. Some lncRNAs have multiple functions (for example, MALAT1 promotes cell proliferation, invasion, migration, and metastasis). Abbreviations: SPRY4-IT1: SPRY4 intronic transcript 1; HOTAIR: Hox transcript antisense intergenic RNA; UCA1: urothelial carcinoma-associated 1; IncRNA-ATB: IncRNA activated by TGF- $\beta$; MALAT1: metastasis-associated lung adenocarcinoma transcript 1; Linc00152: long intergenic noncoding RNA 152; TUG1: Taurine up-regulated gene 1; HEIRCC: high-expressed in renal cell carcinoma, IncRNA TCONS_00006756; CRNDE: colorectal neoplasia differentially expressed; CADM1-AS1: IncRNA cell adhesion molecule 1 antisense, IncRNA (RNA176206/ENST00000546273) located in the antisense direction of a coding exon of the cell adhesion molecule1 (CADM1); TRIM52-AS1: TRIM52 antisense RNA 1; GAS-5: growth arrest specific 5; MEG3: maternally expressed gene 3; TCL6: T-cell leukemia/lymphoma 6; CASC2: cancer susceptibility candidate 2; NBAT-1: neuroblastoma associated transcript 1; SRLR: sorafenib resistance-associated IncRNA in RCC; ARSR: IncRNA activated in RCC with sunitinib resistance, ENST00000424980. 
Table 1: The studies about expression profiling of IncRNAs in RCC

\begin{tabular}{|c|c|c|c|c|c|c|c|c|}
\hline Author & Year & Country & $\begin{array}{c}\text { RCC } \\
\text { subtype }\end{array}$ & $\begin{array}{l}\text { Sample } \\
\text { size (n) }\end{array}$ & $\begin{array}{c}\text { Differentially } \\
\text { expressed IncRNAs }\end{array}$ & $\begin{array}{c}\text { Number } \\
\text { upregulated }\end{array}$ & $\begin{array}{c}\text { Number } \\
\text { downregulated }\end{array}$ & References \\
\hline Yu et al & 2012 & China & $\mathrm{ccRCC}$ & 6 & 726 & 146 & 480 & 37 \\
\hline Liu et al & 2016 & China & $\begin{array}{c}\text { not } \\
\text { mentioned }\end{array}$ & 90 & 3862 & 1649 & 2243 & 38 \\
\hline $\begin{array}{l}\text { Deng, } \\
\text { Blondeau et al }\end{array}$ & 2015 & Germany & ccRCC & 15 & 1308 & 568 & 740 & 39,40 \\
\hline Qin et al & 2014 & China & ccRCC & 5 & 897 & 480 & 417 & 41 \\
\hline Fachel et al & 2013 & Brazil & $\mathrm{ccRCC}$ & 11 & 40 & 14 & 26 & 42 \\
\hline He et al & 2016 & China & $\operatorname{chRCC}$ & 59 & 143 & 41 & 102 & 43 \\
\hline
\end{tabular}

Table 2A: Upregulated IncRNAs in RCC

\begin{tabular}{|c|c|c|c|c|c|}
\hline IncRNAs & Specimens & Functions & Target genes/Signalings & $\begin{array}{c}\text { Pathways/Mechanisms } \\
\text { involved }\end{array}$ & Referances \\
\hline SPRY4-IT1 & RCC tissues, cell lines & oncogene & & $\begin{array}{l}\text { proliferation, migration, } \\
\text { invasion }\end{array}$ & 44 \\
\hline HOTAIR & cell lines & oncogene & $\begin{array}{l}\text { H3K27me, EZH2, } \\
\text { miR-141, Ago2 }\end{array}$ & $\begin{array}{l}\text { proliferation, invasion, cell } \\
\text { cycle }\end{array}$ & 45,46 \\
\hline UCA1 & RCC tissues, cell lines & oncogene & & $\begin{array}{l}\text { proliferation, migration, } \\
\text { apoptosis }\end{array}$ & 47 \\
\hline $\operatorname{lncRNA-ATB}$ & RCC tissues, cell lines & oncogene & EMT & $\begin{array}{l}\text { proliferation, apoptosis, } \\
\text { migration, invasion }\end{array}$ & 48 \\
\hline RCCRT1 & RCC tissues & biomarker & & migration, invasion & 49 \\
\hline MALAT1 & RCC tissues, cell lines & oncogene & Ezh2, miR-205 & $\begin{array}{l}\text { proliferation, migration, } \\
\text { invasion }\end{array}$ & 50,51 \\
\hline Linc00152 & RCC tissues, cell lines & $\begin{array}{l}\text { oncogene, } \\
\text { biomarker }\end{array}$ & & $\begin{array}{l}\text { proliferation, invasion, } \\
\text { apoptosis, cell cycle }\end{array}$ & 52 \\
\hline TUG1 & RCC tissues, cell lines & oncogene & & $\begin{array}{l}\text { migration, invasion, } \\
\text { proliferation, apoptosis }\end{array}$ & 53 \\
\hline H19 & RCC tissues, cell lines & biomarker & & $\begin{array}{l}\text { proliferation, invasion, } \\
\text { migration }\end{array}$ & 54 \\
\hline HEIRCC & RCC tissues, cell lines & oncogene & EMT & $\begin{array}{l}\text { proliferation, apoptosis, } \\
\text { migration, invasion }\end{array}$ & 55 \\
\hline CRNDE & RCC tissues, cell lines & oncogene & Wnt/ $\beta$-catenin signaling & $\begin{array}{l}\text { proliferation, growth, cell } \\
\text { cycle }\end{array}$ & 56 \\
\hline uc009yby.1 & $\mathrm{RCC}$ tissues & oncogene & & proliferation & 57 \\
\hline FTX & RCC tissues, cell lines & oncogene & & $\begin{array}{l}\text { proliferation, cell cycle, } \\
\text { migration, invasion }\end{array}$ & 58 \\
\hline PVT1 & RCC tissues & oncogene & MYC & promoter hypomethylation & 59 \\
\hline
\end{tabular}

deregulated. Wu et al performed a study that demonstrated that five lncRNAs are significantly dysregulated in the serum of RCC patients-lncRNAs (LET, PVT1, PANDAR, PTENP1, and linc00963)- this 5 lncRNAs serum signature may obtain a preferable sensitivity and specificity for distinguishing ccRCC patients from normal individuals [76].

\section{Prognosis}

A multitude of studies have shown that aberrant lncRNA expressions are associated with the disease overall survival (OS), the 5-year survival, the disease-free survival (DFS), the disease grade and stage, recurrence, 
Table 2B: Downregulated IncRNAs in RCC

\begin{tabular}{|c|c|c|c|c|c|}
\hline IncRNAs & Specimens & Functions & Target genes/Signalings & $\begin{array}{c}\text { Pathways/Mechanisms } \\
\text { involved }\end{array}$ & Referances \\
\hline CADM1-AS1 & RCC tissues & $\begin{array}{c}\text { tumor } \\
\text { suppressor }\end{array}$ & CADM1 & $\begin{array}{c}\text { cell proliferation, apoptosis } \\
\text { and migration }\end{array}$ & 60 \\
\hline TRIM52-AS1 & $\mathrm{RCC}$ tissues & $\begin{array}{c}\text { tumor } \\
\text { suppressor }\end{array}$ & & $\begin{array}{l}\text { proliferation, cell migration } \\
\text { and apoptosis }\end{array}$ & 61 \\
\hline GAS-5 & RCC tissues & $\begin{array}{c}\text { tumor } \\
\text { suppressor }\end{array}$ & & $\begin{array}{l}\text { proliferation, apoptosis, cell } \\
\text { cycle, migration, invasion }\end{array}$ & 62 \\
\hline MEG3 & $\begin{array}{l}\text { RCC tissues, cell } \\
\text { lines }\end{array}$ & $\begin{array}{c}\text { tumor } \\
\text { suppressor }\end{array}$ & $\begin{array}{l}\text { Bcl-2, rocaspase-9, leaved } \\
\text { caspase-9, cytochrome c }\end{array}$ & $\begin{array}{c}\text { apoptosis, mitochondrial } \\
\text { pathway }\end{array}$ & 63 \\
\hline BX357664 & $\begin{array}{l}\text { RCC tissues,cell } \\
\text { lines }\end{array}$ & $\begin{array}{c}\text { tumor } \\
\text { suppressor }\end{array}$ & $\begin{array}{c}\text { EMT, MMP2, MMP9, } \\
\text { TGF- } \beta 1 / \text { p38/HSP27 }\end{array}$ & $\begin{array}{l}\text { proliferation, migration, } \\
\text { invasion, cell cycle }\end{array}$ & 64 \\
\hline TCL6 & RCC tissues & $\begin{array}{c}\text { tumor } \\
\text { suppressor }\end{array}$ & & proliferation, apoptosis & 65 \\
\hline $\mathrm{CASC} 2$ & $\begin{array}{l}\text { RCC tissues, cell } \\
\text { lines }\end{array}$ & $\begin{array}{c}\text { tumor } \\
\text { suppressor }\end{array}$ & miR-21 & proliferation, migration & 66 \\
\hline NBAT-1 & $\begin{array}{l}\text { RCC tissues, cell } \\
\text { lines }\end{array}$ & $\begin{array}{l}\text { prognostic } \\
\text { biomarker }\end{array}$ & & $\begin{array}{l}\text { proliferation, migration, } \\
\text { invasion }\end{array}$ & 67 \\
\hline
\end{tabular}

metastasis etc. As shown in Table 3, decreased expression of IncRNA NONHSAT123350, CADM1-AS1, TCL6 and lnc-ZNF180-2 is correlated with poorer prognosis of RCC patients $[38,60,65,68]$. On the other hand, overexpression of SPRY4-IT1, RCCRT1, MALAT1, Linc00152 and PVT1 shows a poor prognosis, as well [44, 49-52, 59].

The expression level of lncRNA NONHSAT123350 was closely associated with OS and DFS in patients without distant metastasis; the median values of OS and DFS were significantly higher among patients with high NONHSAT123350 expression when compared to the patients whose expression of NONHSAT123350 were low [38]. In another study, Ellinger et al reported the expression of lnc-ZNF180-2 significantly increased in advanced ccRCC tissue compared with localized ccRCC and normal renal tissue; a shorter period of progressionfree survival (PFS), cancer-specific survival (CSS), and OS following nephrectomy happened in patients with lower levels of lnc-ZNF180-2 in the univariate Cox regression analysis. Thereafter, lnc-ZNF180-2 expression levels showed an independent predictor of progression-free survival (PSF), CSS, and OS in ccRCC patients within the multivariate Cox regression model [68]. In addition, the ccRCC patients had an advanced clinical stage and poorer prognosis when the SPRY4-IT1 expression was at high level. It is identified that SPRY4-IT1 is an independent prognostic factor in ccRCC in Cox proportional hazard model [44]. DRAIC is a new tumor suppressive sequence which locates on chromosome 15q23. DRAIC lncRNA was identified downregulated as prostate cancer cells progress from an androgen dependent to castration resistant state. DRAIC overexpression indicates a favorable prognosis in many kinds of malignancies including RCC [77]. Recently, a study showed that high Linc00152 expression was closely associated with advanced TNM stage in RCC patients. Moreover, Linc00152 is able to serve as an independent predictor of OS for the patients [52]. In addition, eight lncRNAs transcribed from the loci (ACTN4, CSNK1D, DNAJC3, GIGYF2, HDAC5, PTPN3, RAB25, and VPS13B) were detected as altered in the expression profiles in both of the malignancy and the survival outcomes [42]. Furthermore, PVT1 was strongly overexpressed in ccRCC and associated with the enhancement of MYC signaling and poorer clinical outcome [57].

\section{Therapy}

Good ways to study the potential therapeutic function in cancer include lncRNAs are through loss-offunction or gain-of-function, RNA interfering technology, genetic loss-of-function models, or overexpression [33]. Therapeutic silencing or overexpression of these lncRNAs might be a viable therapeutic option to reduce the growth and/or metastatic potential of RCC. LncRNAs that may serve as therapeutic targets for RCC are listed in Table 4 and discussed as below.

\section{HOTAIR}

HOTAIR is transcribed from antisense strand of HOXC gene cluster present in chromosome 12 with a 
Table 3: Prognostic IncRNAs in RCC

\begin{tabular}{lcc}
\hline IncRNAs & Prognostic information & Referances \\
\hline CADM1-AS1 & decreased expression, poor prognosis (OS) & 60 \\
TCL6 & low expression, poor prognosis (OS) & 65 \\
NONHSAT123350 & low expression, poor prognosis (DFS,OS) & 38 \\
lnc-ZNF180-2 & low level, poor progression-free, CSS and OS & 68 \\
SPRY4-IT1 & high expression, poor prognosis (OS) & 44 \\
RCCRT1 & high expression, poor survival & 49 \\
MALAT1 & high expression, poor prognosis (OS) & 50 \\
Linc00152 & high expression, poor prognosis (OS) & 52 \\
DRAIC & overexpression, good prognosis & 77 \\
PVT1 & high expression, poor prognosis (OS) & 59 \\
\hline
\end{tabular}

length of $2.2 \mathrm{~kb}$ [78]. Recent study find that it can regulate EMT and is involved in Notch pathway [79]. Moreover, HOTAIR is a target of miR-141, inhibiting HOTAIR function in an Ago2-dependent manner [46]. Through RNAi technology, HOTAIR knockdown can affect cell cycle in $\mathrm{G} 0 / \mathrm{G} 1$ phase and decrease cell proliferation and invasion of RCC cells [45]. The inhibiton of HOTAIR also suppressed tumor formation in the xenograft experiments in vivo [45]. Further studies are urgent for determining the regulatory mechanisms of HOTAIR, together with the interactions with epigenetic processes, such as DNA methylation, histone modification, microRNA and ubiquitin, by which new therapeutic targets might be developed in the treatment of RCC.

\section{RCCRT1}

RCCRT1 is upregulated in RCC compared with tumor adjacent tissue, particularly in high-grade RCC tissue. It is considered to be an oncogene of RCC, and elevated expression of RCCRT1 may predict dismal survival of RCC patients [49]. The knockdown of RCCRT1 by RNAi technique can suppress migration and invasion in RCC cell lines [49].

\section{MALAT1}

MALAT1 also called nuclear-enriched abundant transcript 2 (NEAT2) or Mhrt, it is one of the up-regulated nuclear IncRNAs in mammals [82]. The expression of MALAT1 is found to be upregulated in RCC tissues compared with corresponding normal tissues $[50,51]$. Over-expression of MALAT1 indicates a more aggressive feature of the tumor and predicts a poorer OS than downexpression of MALAT1 in patients with ccRCC $[50,51]$. In vitro experiments found that the inhibition of MALAT1 not only suppressed cell proliferation, promoted apoptosis, but also inhibited migration, and invasion of RCC cells $[50,51]$. Thus, inhibition of MALAT1 may become a promising strategy for RCC therapy.
H19

The lncRNA H19 is another well-known oncogene in various cancer types, tumorigenesis, and cancer progression. It is transcribed from the sequence localized at $11 \mathrm{p} 15.5$ of the human genome. It is associate with disease progression and poorer prognosis of RCC patients [54]. Moreover, inhibition of H19 can suppress proliferation, invasion, and migration of RCC cells [54].

\section{CADM1-AS1}

LncRNA CADM1-AS is considered to be involved in the carcinogenesis of RCC. It is found to be decreased in RCC tissues [60]. Down-regulation of CADM1AS1 correlates with advanced disease staging and poor prognosis of patients with ccRCC [60]. Over-expression of CADM1-AS1 can significantly decrease cell growth and migration, as well as increase apoptosis in RCC cells [60]. Therefore, CADMA1-AS1 maybe become a suitable therapeutic marker for RCC.

\section{LncRNA-SRLR and IncARSR}

Targeted therapy drugs, such as sorafenib and sunitinib, appear to increase the survival rate of RCC patients. But targeted therapy resistance is a major obstacle for the treatment of advanced and/or metastatic RCC. LncRNA-SRLR (sorafenib resistance-associated lncRNA in RCC) was found upregulated in intrinsically sorafenib resistant RCCs. Interestingly, IncRNA-SRLR knockdown sensitized nonresponsive RCC cells to sorafenib treatment, whereas the overexpression of IncRNA-SRLR conferred sorafenib resistance to responsive RCC cells. The underlying mechanism is that IncRNA-SRLR directly binds to NF- $\mathrm{kB}$ and promotes IL-6 transcription, leading to the activation of STAT3 and the development of sorafenib tolerance. A STAT3 inhibitor and IL-6-receptor antagonist both restored the response to sorafenib treatment. Moreover, high levels of lncRNA-SRLR correlated with poor responses to sorafenib therapy in RCC patients [87]. 
Table 4: LncRNAs potentially serve as therapeutic targets for RCC

\begin{tabular}{|c|c|c|c|}
\hline LncRNAs & Location & Properties/Mechanisms & References \\
\hline \multirow[t]{7}{*}{ HOTAIR } & chromosome 12 & $\begin{array}{l}\text { recruit and bind on the locus of EZH2 and } \\
\qquad \mathrm{H} 3 \mathrm{~K} 27 \mathrm{me} 3\end{array}$ & 80 \\
\hline & & inhibit cycle-related genes p53, p21 and p16 & 80 \\
\hline & & modulate covalent histones & 80 \\
\hline & & $\begin{array}{l}\text { interact with methyltransferase PRC2, histone } \\
\text { demethylase LSD1 }\end{array}$ & 80 \\
\hline & & regulates gene silencing & 80 \\
\hline & & required for $\mathrm{H} 3 \mathrm{~K} 27$ trimethylation & 81 \\
\hline & & $\begin{array}{c}\text { transcriptional silencing across the HOXD } \\
\text { locus }\end{array}$ & 81 \\
\hline \multirow[t]{2}{*}{ RCCRT1 } & $\begin{array}{l}\operatorname{chr} 5: 137801181- \\
137805004\end{array}$ & upregulated in $\mathrm{RCC}$ & 49 \\
\hline & & upregulated predicts poor survival of RCC & 49 \\
\hline \multirow[t]{8}{*}{ MALAT1 } & chromosome 11q13 & independent predictor of OS in ccRCC & 50,51 \\
\hline & & $\begin{array}{c}\text { sequester serine/arginine splicing factors in } \\
\text { nuclear speckle domains }\end{array}$ & 83,84 \\
\hline & & regulate alternative splicing & 84 \\
\hline & & $\begin{array}{l}\text { transcriptional activation of MALAT1 by c-Fos } \\
\text { contribute to oncogenesis }\end{array}$ & 51 \\
\hline & & interact with Ezh2 & 51 \\
\hline & & reciprocally repressed with miR205 & 51 \\
\hline & & regulate EMT via E-cadherin and $\beta$-catenin & 51 \\
\hline & & $\begin{array}{l}\text { promote ZEB2 expression by sponging miR- } \\
\qquad 200 \mathrm{~s}\end{array}$ & 85 \\
\hline \multirow[t]{2}{*}{ H19 } & $11 \mathrm{p} 15.5$ & $\begin{array}{c}\text { exon } 1 \text { of H19 harbors a miRNA-containing } \\
\text { hairpin }\end{array}$ & 86 \\
\hline & & $\begin{array}{l}\text { serve as the template of two miR6755p and } \\
\text { miR6753p }\end{array}$ & 86 \\
\hline LncRNA-SRLR & $3 q 24$ & $\begin{array}{l}\text { upregulated in intrinsically sorafenib resistant } \\
\text { RCC }\end{array}$ & 87 \\
\hline \multirow[t]{5}{*}{ LncARSR } & $\begin{array}{l}9 \mathrm{q} 82.120 .717- \\
82.185 .824\end{array}$ & promote sunitinib resistance of RCC & 88 \\
\hline & & competitively bind to miR-34/miR-449 & 88 \\
\hline & & facilitate AXL and c-MET expression & 88 \\
\hline & & $\begin{array}{c}\text { exosome-transferred lncARSR confer sunitinib } \\
\text { resistance }\end{array}$ & 88 \\
\hline & & $\begin{array}{c}\text { targeting lncARSR restores sunitinib response } \\
\text { in RCC }\end{array}$ & 88 \\
\hline CADM1-AS1 & $\begin{array}{l}\text { antisense direction of a } \\
\text { coding exon of } \\
\text { the cell adhesion } \\
\text { molecule } 1 \text { (CADM1) }\end{array}$ & $\begin{array}{l}\text { involved in renal carcinogenesis } \\
\text { independent prognostic factor for ccRCC }\end{array}$ & $\begin{array}{l}60 \\
60\end{array}$ \\
\hline
\end{tabular}


LncARSR (activated in RCC with sunitinib resistance, ENST00000424980) was a newly identified lncRNA to promote the sunitinib resistance of RCC. It is upregulated in sunitinib resistant RCC. By targeting lncARSR and the underlining pathways involved, sunitinib resistance RCC can restore the sensitivity to sunitinib [88]. Another study showed that lncARSR was upregulated in primary renal cancer stem cells (CSCs) and was associated with a poor prognosis of ccRCC. Knockdown of lncARSR attenuated the self-renewal, tumorigenicity, and metastasis of renal CSCs. Conversely, forced lncARSR expression enhanced CSC properties of RCC cells. The mechanism showed that the binding of lncARSR to Yes-associated protein (YAP) impedes LATS1-induced YAP phosphorylation and facilitates YAP nuclear translocation [89].

These findings are extremely meaningful, because lncRNAs may act as predictors and potential promising therapeutic targets for target therapy resistance, and may further improve the management of RCC patients receiving target therapy. If these lncRNAs could be applied to the treatment of RCC, it would benefit the patients, not only on efficacy, but also economically. Hence, further studies should be made for the identification of lncRNAs as targeted therapy biomarkers and application for RCC treatment strategy.

\section{Specific molecular mechanism of Incrnas in RCC}

Hypoxia-inducible factor-2 $\alpha$ (HIF2A) signaling participates in the RCC oncogenesis and progression as reported [90]. In this pathway, LncRNA-suppressing androgen receptor in renal cell carcinoma (SARCC) serves as a critical regulator, it connects with the AR/ $\mathrm{HIF} 2 \mathrm{~A} / \mathrm{MYC}$ axis to regulate cell growth in response to hypoxia. LncRNA-SARCC suppresses hypoxic cell cycle progression in VHL mutant type of $\mathrm{RCC}$ cells and de-represses it in VHL restored type of RCC cells. Mechanistically, lncRNA-SARCC binds to and deactivates androgen receptor (AR) protein to modulate AR post transcription thus block the AR/HIF2A/ MYC signals; on the other hand, HIF2A is able to regulate the IncRNA-SARCC expression on the transcription level by binding to hypoxia responsive elements on the lncRNASARCC promoter vice versa [90]. There is a negative feedback regulation loop between complex of LncRNASARCC/AR and HIF2A pathway, by which may result a differentially regulated $\mathrm{RCC}$ disease progression in a VHL dependent way [90]. Thereafter, future studies should be done to identify the association of lncRNAs and HIF signals in RCC.

Interestingly, a recent study from China established a novel method designed to identify lncRNA competitively regulated signal subpathways, so called subpathway-LNCE, which can identify lncRNA competitively regulated functions. The functional roles of these competitive regulation lncRNAs have not be well characterized in diseases. Moreover, the method integrated lncRNA-mRNA expression profile and pathway topologies [91].

\section{CONCLUSIONS}

In conclusion, lncRNAs are aberrantly expressed in RCC, and participate in important roles in the regulation of RCC. They have a significant impact on our understanding the mechanisms of pathogenesis, progression and metastasis of RCC. They are also involve in key pathological process in RCC, the cell proliferation, cell cycle control, apoptosis, local invasion and distal metastasis. To deeply identify the mechanisms regarding how specific lncRNAs affect RCC and the regulatory mechanisms, further exploration and continued studies are required. At the same time, the IncRNA transduction pathway in RCC still needs to be further explored. Moreover, lncRNAs may act as promising new biomarkers for RCC, with the capability of improving diagnosis, predicting prognosis, and even in the improvement of therapeutic strategy for RCC patients. Several newly identified lncRNAs have the function of predicting target therapy resistance, by targeting these lncRNAs, the resistance of target therapies may be restored their sensitivity. RCC is an immunotherapy effective disease and the determination of whether lncRNAs could regulate the immune pathways of RCC such as PD-1 or PD-L1 signaling are expected. In any cases, to deeply understand the mechanisms of lncRNAs in RCC can not only help to uncover the tumorigenesis, but also have the possibility of application in the clinical management.

\section{ACKNOWLEDGMENTS}

This work was supported by the Promising Talents Plan Program Funding of Shengjing Hospital, China Medical University. The authors are very grateful to the reviewers and editors, without their help, we could not complete this work. We apologize to those whose research we could not cite due to the limitations of our topic and space.

\section{CONFLICTS OF INTEREST}

The authors declare that they have no conflicts of interest.

\section{REFERENCES}

1. Siegel RL, Miller KD, Jemal A. Cancer statistics, 2016. CA Cancer J Clin. 2016; 66:7-30. doi: 10.3322/ caac. 21332 .

2. Chen W, Zheng R, Baade PD, Zhang S, Zeng H, Bray F, Jemal A, Yu XQ, He J. Cancer statistics in China, 2015. CA Cancer J Clin. 2016; 66:115-32. doi: 10.3322/caac.21338. 
3. Vera-Badillo FE, Conde E, Duran I. Chromophobe renal cell carcinoma: A review of an uncommon entity. Int J Urol. 2012; 19:894-900. doi: 10.1111/j.1442-2042.2012.03079.x.

4. Moch H, Cubilla AL, Humphrey PA, Reuter VE, Ulbright TM. The 2016 WHO Classification of Tumours of the Urinary System and Male Genital Organs-Part A: Renal, Penile, and Testicular Tumours. Eur Urol. 2016; 70:93-105. doi: 10.1016/j.eururo.2016.02.029.

5. Cancer Genome Atlas Research Network. Comprehensive molecular characterization of clear cell renal cell carcinoma. Nature. 2013; 499:43-9. doi: 10.1038/ nature12222.

6. Di Cristofano C, Minervini A, Menicagli M, Salinitri G, Bertacca G, Pefanis G, Masieri L, Lessi F, Collecchi P, Minervini R, Carini M, Bevilacqua G, Cavazzana A. Nuclear expression of hypoxia-inducible factor-1alpha in clear cell renal cell carcinoma is involved in tumor progression. Am J Surg Pathol. 2007; 31:1875-81. doi: 10.1097/PAS.0b013e318094fed8.

7. Elfiky AA, Aziz SA, Conrad PJ, Siddiqui S, Hackl W, Maira M, Robert CL, Kluger HM. Characterization and targeting of phosphatidylinositol-3 kinase (PI3K) and mammalian target of rapamycin (mTOR) in renal cell cancer. J Transl Med. 2011; 9:133. doi: 10.1186/1479-5876-9-133.

8. Chappell WH, Steelman LS, Long JM, Kempf RC, Abrams SL, Franklin RA, Bäsecke J, Stivala F, Donia M, Fagone P, Malaponte G, Mazzarino MC, Nicoletti F, et al. Ras/ Raf/MEK/ERK and PI3K/PTEN/Akt/mTOR inhibitors: rationale and importance to inhibiting these pathways in human health. Oncotarget. 2011; 2:135-65. doi: 10.18632/ oncotarget.240.

9. Shang D, Liu Y, Ito N, Kamoto T, Ogawa O. Defective JakStat activation in renal cell carcinoma is associated with interferon-alpha resistance. Cancer Sci. 2007; 98:1259-64. doi: 10.1111/j.1349-7006.2007.00526.x.

10. Xu Q, Krause M, Samoylenko A, Vainio S. Wnt Signaling in Renal Cell Carcinoma. Cancers (Basel). 2016; 8. doi: 10.3390/cancers8060057.

11. Li M, Wang Y, Song Y, Bu R, Yin B, Fei X, Guo Q, Wu B. Expression profiling and clinicopathological significance of DNA methyltransferase 1, 3A and 3B in sporadic human renal cell carcinoma. Int J Clin Exp Pathol. 2014; 7:7597-609.

12. Mosashvilli D, Kahl P, Mertens C, Holzapfel S, Rogenhofer S, Hauser S, Buttner R, Von Ruecker A, Muller SC, Ellinger J. Global histone acetylation levels: prognostic relevance in patients with renal cell carcinoma. Cancer Sci. 2010; 101:2664-9. doi: 10.1111/j.1349-7006.2010.01717.x.

13. Li M, Wang Y, Song Y, Bu R, Yin B, Fei X, Guo Q, Wu B. MicroRNAs in renal cell carcinoma: a systematic review of clinical implications (Review). Oncol Rep. 2015; 33:15718. doi: 10.3892/or.2015.3799.

14. Hangauer MJ, Vaughn IW, McManus MT. Pervasive transcription of the human genome produces thousands of previously unidentified long intergenic noncoding RNAs. PLoS Genet. 2013; 9:e1003569. doi: 10.1371/journal. pgen. 1003569.

15. Consortium EP. An integrated encyclopedia of DNA elements in the human genome. Nature. 2012; 489:57-74. doi: 10.1038/nature11247.

16. Bierhoff H, Schmitz K, Maass F, Ye J, Grummt I. Noncoding transcripts in sense and antisense orientation regulate the epigenetic state of ribosomal RNA genes. Cold Spring Harb Symp Quant Biol. 2010; 75:357-64. doi: 10.1101/sqb.2010.75.060.

17. Guttman M, Amit I, Garber M, French C, Lin MF, Feldser D, Huarte M, Zuk O, Carey BW, Cassady JP, Cabili MN, Jaenisch R, Mikkelsen TS, et al. Chromatin signature reveals over a thousand highly conserved large non-coding RNAs in mammals. Nature. 2009; 458:223-7. doi: 10.1038/ nature 07672 .

18. St Laurent G, Wahlestedt C, Kapranov P. The Landscape of long noncoding RNA classification. Trends Genet. 2015; 31:239-51. doi: 10.1016/j.tig.2015.03.007.

19. Schmitt AM, Chang HY. Long Noncoding RNAs in Cancer Pathways. Cancer Cell. 2016; 29:452-63. doi: 10.1016/j. ccell.2016.03.010.

20. Goodrich JA, Kugel JF. Non-coding-RNA regulators of RNA polymerase II transcription. Nat Rev Mol Cell Biol. 2006; 7:612-6. doi:10.1038/nrm1946.

21. Kwek KY, Murphy S, Furger A, Thomas B, O'Gorman W, Kimura H, Proudfoot NJ, Akoulitchev A. U1 snRNA associates with TFIIH and regulates transcriptional initiation. Nat Struct Biol. 2002; 9:800-5. doi: 10.1038/ nsb862.

22. Mariner PD, Walters RD, Espinoza CA, Drullinger LF, Wagner SD, Kugel JF, Goodrich JA. Human Alu RNA is a modular transacting repressor of mRNA transcription during heat shock. Mol Cell. 2008; 29:499-509. doi: 10.1016/j.molcel.2007.12.013.

23. Martianov I, Ramadass A, Serra Barros A, Chow N, Akoulitchev A. Repression of the human dihydrofolate reductase gene by a non-coding interfering transcript. Nature. 2007; 445:666-70. doi: 10.1038/nature05519.

24. Dieci G, Fiorino G, Castelnuovo M, Teichmann M, Pagano A. The expanding RNA polymerase III transcriptome. Trends Genet. 2007; 23:614-22. doi: 10.1016/j. tig.2007.09.001.

25. Pagano JM, Farley BM, McCoig LM, Ryder SP. Molecular basis of RNA recognition by the embryonic polarity determinant MEX-5. J Biol Chem. 2007; 282:8883-94. doi: 10.1074/jbc.M700079200.

26. Tripathi V, Ellis JD, Shen Z, Song DY, Pan Q, Watt AT, Freier SM, Bennett CF, Sharma A, Bubulya PA, Blencowe BJ, Prasanth SG, Prasanth KV. The nuclear-retained noncoding RNA MALAT1 regulates alternative splicing by modulating SR splicing factor phosphorylation. Mol Cell. 2010; 39:925-38. doi: 10.1016/j.molcel.2010.08.011. 
27. Majidinia M, Mihanfar A, Rahbarghazi R, Nourazarian A, Bagca B, Avci CB. The roles of non-coding RNAs in Parkinson's disease. Mol Biol Rep. 2016; 43:1193-204. doi: 10.1007/s11033-016-4054-3.

28. Czech B, Malone CD, Zhou R, Stark A, Schlingeheyde C, Dus M, Perrimon N, Kellis M, Wohlschlegel JA, Sachidanandam R, Hannon GJ, Brennecke J. An endogenous small interfering RNA pathway in Drosophila. Nature. 2008; 453:798-802. doi: 10.1038/nature07007.

29. Pauler FM, Koerner MV, Barlow DP. Silencing by imprinted noncoding RNAs: is transcription the answer? Trends Genet. 2007; 23:284-92. doi: 10.1016/j.tig.2007.03.018.

30. Schoeftner S, Blasco MA. Developmentally regulated transcription of mammalian telomeres by DNA-dependent RNA polymerase II. Nat Cell Biol. 2008; 10:228-36. doi: $10.1038 /$ ncb1685.

31. Azzalin CM, Reichenbach P, Khoriauli L, Giulotto E, Lingner J. Telomeric repeat- containing RNA and RNA surveillance factors at mammalian chromosome ends. Science. 2007; 318:798-801. doi: 10.1126/science.1147182.

32. Furlan G, Rougeulle C. Function, and evolution of the long noncoding RNA circuitry orchestrating X-chromosome inactivation in mammals. Wiley Interdiscip Rev RNA. 2016; 7:702-22. doi: 10.1002/wrna.1359.

33. Gutschner T, Diederichs S. The hallmarks of cancer: a long non-coding RNA point of view. RNA Biol. 2012; 9:703-19. doi: $10.4161 /$ rna.20481.

34. Rinn JL, Kertesz M, Wang JK, Squazzo SL, Xu X, Brugmann SA, Goodnough LH, Helms JA, Farnham PJ, Segal E, Chang HY. Functional demarcation of active and silent chromatin domains in human HOX loci by noncoding RNAs. Cell. 2007; 129:1311-23. doi: 10.1016/j. cell.2007.05.022.

35. Chen J, Chen Y, Gu L, Li X, Gao Y, Lyu X, Chen L, Luo G, Wang L, Xie Y, Duan J, Peng C, Ma X. LncRNAs act as prognostic and diagnostic biomarkers in renal cell carcinoma a systematic review and meta-analysis. Oncotarget. 2016; 7:74325-74336. doi: 10.18632/ oncotarget.11101.

36. Li Z, Chen Y, Hu S, Zhang J, Wu J, Ren W, Shao N, Ying $\mathrm{X}$. Integrative analysis of protein-coding and non-coding RNAs identifies clinically relevant subtypes of clear cell renal cell carcinoma. Oncotarget. 2016; 7:82671-82685. doi: 10.18632/oncotarget.12340.

37. Yu G, Yao W, Wang J, Ma X, Xiao W, Li H, Xia D, Yang Y, Deng K, Xiao H, Wang B, Guo X, Guan W, et al. LncRNAs expression signatures of renal clear cell carcinoma revealed by microarray. PLoS One. 2012; 7:e42377. doi: 10.1371/ journal.pone.0042377.

38. Liu H, Chen P, Jiang C, Han J, Zhao B, Ma Y, Mardan M. Screening for the Key lncRNA Targets Associated With Metastasis of Renal Clear Cell Carcinoma. Medicine (Baltimore). 2016; 95:e2507. doi: 10.1097/ MD.0000000000002507.
39. Deng M, Blondeau JJ, Schmidt D, Perner S, Muller SC, Ellinger J. Identification of novel differentially expressed lncRNA and mRNA transcripts in clear cell renal cell carcinoma by expression profiling. Genom Data. 2015; 5:173-5. doi: 10.1016/j.gdata.2015.06.016.

40. Blondeau JJ, Deng M, Syring I, Schroder S, Schmidt D, Perner S, Muller SC, Ellinger J. Identification of novel long non-coding RNAs in clear cell renal cell carcinoma. Clin Epigenetics. 2015; 7:10. doi: 10.1186/s13148-015-0047-7.

41. Castresana JS, Qin C, Han Z, Qian J, Bao M, Li P, Ju X, Zhang S, Zhang L, Li S, Cao Q, Lu Q, Li J, et al. Expression Pattern of Long Non-Coding RNAs in Renal Cell Carcinoma Revealed by Microarray. PLoS ONE. 2014; 9:e99372. doi: 10.1371/journal.pone.0099372.

42. Fachel AA, Tahira AC, Vilella-Arias SA, MaracajaCoutinho V, Gimba ER, Vignal GM, Campos FS, Reis EM, Verjovski-Almeida S. Expression analysis and in silico characterization of intronic long non-coding RNAs in renal cell carcinoma: emerging functional associations. Mol Cancer. 2013; 12:140. doi: 10.1186/1476-4598-12-140.

43. He HT, Xu M, Kuang Y, Han XY, Wang MQ, Yang Q. Biomarker and competing for endogenous RNA potential of tumor-specific long noncoding RNA in chromophobe renal cell carcinoma. Onco Targets Ther. 2016; 9:6399-6406. doi: 10.2147/OTT.S116392.

44. Zhang HM, Yang FQ, Yan Y, Che JP, Zheng JH. High expression of long non-coding RNA SPRY4-IT1 predicts poor prognosis of clear cell renal cell carcinoma. Int J Clin Exp Pathol. 2014; 7:5801-9.

45. Wu Y, Liu J, Zheng Y, You L, Kuang D, Liu T. Suppressed expression of long non-coding RNA HOTAIR inhibits proliferation and tumourigenicity of renal carcinoma cells. Tumour Biol. 2014; 35:11887-94. doi: 10.1007/ s13277-014-2453-4.

46. Chiyomaru T, Fukuhara S, Saini S, Majid S, Deng G, Shahryari V, Chang I, Tanaka Y, Enokida H, Nakagawa M, Dahiya R, Yamamura S. Long non-coding RNA HOTAIR is targeted and regulated by miR-141 in human cancer cells. J Biol Chem. 2014; 289:12550-65. doi: 10.1074/jbc. M113.488593.

47. Li Y, Wang T, Li Y, Chen D, Yu Z, Jin L, Ni L, Yang S, Mao $\mathrm{X}$, Gui Y, Lai Y. Identification of long-non-coding RNA UCA1 as an oncogene in renal cell carcinoma. Mol Med Rep. 2016; 13:3326-34. doi: 10.3892/mmr.2016.4894.

48. Xiong J, Liu Y, Jiang L, Zeng Y, Tang W. High expression of long non-coding RNA lncRNA-ATB is correlated with metastases and promotes cell migration and invasion in renal cell carcinoma. Jpn J Clin Oncol. 2016; 46:378-84. doi: 10.1093/jjco/hyv214.

49. Song S, Wu Z, Wang C, Liu B, Ye X, Chen J, Yang Q, Ye $\mathrm{H}$, Xu B, Wang L. RCCRT1 is correlated with prognosis and promotes cell migration and invasion in renal cell carcinoma. Urology. 2014; 84:730 e1-7. doi: 10.1016/j. urology.2014.05.033. 
50. Zhang HM, Yang FQ, Chen SJ, Che J, Zheng JH. Upregulation of long non-coding RNA MALAT1 correlates with tumor progression and poor prognosis in clear cell renal cell carcinoma. Tumour Biol. 2015; 36:2947-55. doi: 10.1007/s13277-014-2925-6.

51. Hirata H, Hinoda Y, Shahryari V, Deng G, Nakajima K, Tabatabai ZL, Ishii N, Dahiya R. Long Noncoding RNA MALAT1 Promotes Aggressive Renal Cell Carcinoma through Ezh2 and Interacts with miR-205. Cancer Res. 2015; 75:1322-31. doi: 10.1158/0008-5472.CAN-14-2931.

52. Wu Y, Tan C, Weng WW, Deng Y, Zhang QY, Yang XQ, Gan HL, Wang T, Zhang PP, Xu MD, Wang YQ, Wang CF. Long non-coding RNA Linc00152 is a positive prognostic factor for and demonstrates malignant biological behavior in clear cell renal cell carcinoma. Am J Cancer Res. 2016; 6:285-99.

53. Zhang M, Lu W, Huang Y, Shi J, Wu X, Zhang X, Jiang R, Cai Z, Wu S. Downregulation of the long noncoding RNA TUG1 inhibits the proliferation, migration, invasion and promotes apoptosis of renal cell carcinoma. J Mol Histol. 2016; 47:421-8. doi: 10.1007/s10735-016-9683-2.

54. Wang L, Cai Y, Zhao X, Jia X, Zhang J, Liu J, Zhen H, Wang T, Tang X, Liu Y, Wang J. Down-regulated long non-coding RNA H19 inhibits carcinogenesis of renal cell carcinoma. Neoplasma. 2015; 62:412-8. doi: 10.4149/ neo_2015_049.

55. Xiong J, Liu Y, Luo S, Jiang L, Zeng Y, Chen Z, Shi X, Lv $\mathrm{B}$, Tang W. High expression of the long non-coding RNA HEIRCC promotes Renal Cell Carcinoma metastasis by inducing epithelial-mesenchymal transition. Oncotarget. 2017; 8:6555-6563. doi: 10.18632/oncotarget.14149.

56. Shao K, Shi T, Yang Y, Wang X, Xu D, Zhou P. Highly expressed lncRNA CRNDE promotes cell proliferation through Wnt/ $\beta$-catenin signaling in renal cell carcinoma. Tumour Biol. 2016 Oct 6. doi: 10.1007/s13277-016-5440-0. [Epub ahead of print].

57. Ren X, Lan T, Chen Y, Shao Z, Yang C, Peng J. lncRNA uc009yby.1 promotes renal cell proliferation and is associated with poor survival in patients with clear cell renal cell carcinomas. Oncol Lett. 2016; 12:1929-1934. doi: 10.3892/ol.2016.4856

58. He X, Sun G, Guo F, Wang K, Gao Y, Feng Y, Song B, Li W, Li Y. Knockdown of long non-coding RNA FTX inhibits proliferation, migration, and invasion in renal cell carcinoma cells. Oncol Res. 2016 Oct 26. doi: 10.3727/096 504016X14719078133203. [Epub ahead of print].

59. Posa I, Carvalho S, Tavares J, Grosso AR. A pan-cancer analysis of MYC-PVT1 reveals CNV-unmediated deregulation and poor prognosis in renal carcinoma. Oncotarget. 2016; 7:47033-47041. doi: 10.18632/ oncotarget.9487.

60. Yao J, Chen Y, Wang Y, Liu S, Yuan X, Pan F, Geng P. Decreased expression of a novel lncRNA CADM1-AS1 is associated with poor prognosis in patients with clear cell renal cell carcinomas. Int J Clin Exp Pathol. 2014; 7:2758-67.

61. Liu Z, Yan HY, Xia SY, Zhang C, Xiu YC. Downregulation of long non-coding RNA TRIM52-AS1 functions as a tumor suppressor in renal cell carcinoma. Mol Med Rep. 2016; 13:3206-12. doi: 10.3892/mmr.2016.4908.

62. Qiao HP, Gao WS, Huo JX, Yang ZS. Long Non-coding RNA GAS5 Functions as a Tumor Suppressor in Renal Cell Carcinoma. Asian Pacific Journal of Cancer Prevention. 2013; 14:1077-82. doi: 10.7314/apjcp.2013.14.2.1077.

63. Wang M, Huang T, Luo G, Huang C, Xiao XY, Wang L, Jiang GS, Zeng FQ. Long non-coding RNA MEG3 induces renal cell carcinoma cells apoptosis by activating the mitochondrial pathway. J Huazhong Univ Sci Technolog Med Sci. 2015; 35:541-5. doi: 10.1007/s11596-015-1467-5.

64. Liu Y, Qian J, Li X, Chen W, Xu A, Zhao K, Hua Y, Huang Z, Zhang J, Liang C, Su S, Li P, Shao P, et al. Long noncoding RNA BX357664 regulates cell proliferation and epithelial-to-mesenchymal transition via inhibition of TGF- $\beta 1 /$ p38/HSP27 signaling in renal cell carcinoma. Oncotarget. 2016; 7:81410-81422. doi: 10.18632/ oncotarget. 12937.

65. Su H, Sun T, Wang H, Shi G, Zhang H, Sun F, Ye D. Decreased TCL6 expression is associated with poor prognosis in patients with clear cell renal cell carcinoma. Oncotarget. 2017; 8:5789-5799. doi: 10.18632/ oncotarget.11011.

66. Cao Y, Xu R, Xu X, Zhou Y, Cui L, He X. Downregulation of lncRNA CASC2 by microRNA-21 increases the proliferation and migration of renal cell carcinoma cells. Mol Med Rep. 2016; 14:1019-25. doi: 10.3892/ mmr.2016.5337.

67. Xue S, Li QW, Che JP, Guo Y, Yang FQ, Zheng JH. Decreased expression of long non-coding RNA NBAT-1 is associated with poor prognosis in patients with clear cell renal cell carcinoma. Int J Clin Exp Pathol. 2015; 8:3765-74

68. Ellinger J, Alam J, Rothenburg J, Deng M, Schmidt D, Syring I, Miersch H, Perner S, Müller SC. The long noncoding RNA lnc-ZNF180-2 is a prognostic biomarker in patients with clear cell renal cell carcinoma. Am J Cancer Res. 2015; 5:2799-807.

69. Duan W, Du L, Jiang X, Wang R, Yan S, Xie Y, Yan K, Wang Q, Wang L, Zhang X, Pan H, Yang Y, Wang C. Identification of a serum circulating lncRNA panel for the diagnosis and recurrence prediction of bladder cancer. Oncotarget. 2016; 7:78850-78858. doi: 10.18632/ oncotarget. 12880 .

70. Zheng C, Hao H, Chen L, Shao J. Long noncoding RNAs as novel serum biomarkers for the diagnosis of hepatocellular carcinoma: a systematic review and meta-analysis. Clin Transl Oncol. 2017 Feb 10. doi: 10.1007/s12094-017-16261. [Epub ahead of print]. 
71. Yang JP, Yang XJ, Xiao L, Wang Y. Long noncoding RNA PVT1 as a novel serum biomarker for detection of cervical cancer. Eur Rev Med Pharmacol Sci. 2016; 20:3980-3986.

72. Jin C, Shi W, Wang F, Shen X, Qi J, Cong H, Yuan J, Shi L, Zhu B, Luo X, Zhang Y, Ju S. Long non-coding RNA HULC as a novel serum biomarker for diagnosis and prognosis prediction of gastric cancer. Oncotarget. 2016; 7:51763-51772. doi: 10.18632/oncotarget.10107.

73. Wang C, Yu J, Han Y, Li L, Li J, Li T, Qi P. Long noncoding RNAs LOC285194, RP11-462C24.1 and Nbla12061 in serum provide a new approach for distinguishing patients with colorectal cancer from healthy controls. Oncotarget. 2016; 7:70769-70778. doi: 10.18632/oncotarget.12220.

74. Liu T, Zhang X, Gao S, Jing F, Yang Y, Du L, Zheng G, Li P, Li C, Wang C. Exosomal long noncoding RNA CRNDE-h as a novel serum-based biomarker for diagnosis and prognosis of colorectal cancer. Oncotarget. 2016; 7:85551-85563. doi: 10.18632/oncotarget.13465.

75. Miao Y, Fan R, Chen L, Qian H. Clinical Significance of Long Non-coding RNA MALAT1 Expression in Tissue and Serum of Breast Cancer. Ann Clin Lab Sci. 2016; 46:418-24.

76. Wu Y, Wang YQ, Weng WW, Zhang QY, Yang XQ, Gan HL, Yang YS, Zhang PP, Sun MH, Xu MD, Wang CF. A serum circulating long non-coding RNA signature can discriminate between patients with clear cell renal cell carcinoma and healthy controls. Oncogenesis. 2016; 5:e192. doi: 10.1038/oncsis.2015.48.

77. Sakurai K, Reon BJ, Anaya J, Dutta A. The lncRNA DRAIC/PCAT29 Locus Constitutes a Tumor-Suppressive Nexus. Mol Cancer Res. 2015; 13:828-838.

78. Rinn JL, Kertesz M, Wang JK, Squazzo SL, Xu X, Brugmann SA, Goodnough LH, Helms JA, Farnham PJ, Segal E, Chang HY. Functional demarcation of active and silent chromatin domains in human HOX loci by noncoding RNAs. Cell. 2007; 129:1311-23. doi: 10.1016/j. cell.2007.05.022.

79. Lee M, Kim HJ, Kim SW, Park SA, Chun KH, Cho NH, Song YS, Kim YT. The long non-coding RNA HOTAIR increases tumour growth and invasion in cervical cancer by targeting the Notch pathway. Oncotarget. 2016; 7:4455844571. doi: 10.18632/oncotarget.10065.

80. Bhan A, Mandal SS. LncRNA HOTAIR: a master regulator of chromatin dynamics and cancer. Biochim Biophys Acta. 2015; 1856:151-64. doi: 10.1016/j.bbcan.2015.07.001.

81. Tsai MC, Manor O, Wan Y, Mosammaparast N, Wang JK, Lan F, Shi Y, Segal E, Chang HY. Long noncoding RNA as modular scaffold of histone modification complexes. Science. 2010; 329:689-93. doi: 10.1126/science.1192002.

82. Ma XY, Wang JH, Wang JL, Ma CX, Wang XC, Liu FS. Malat1 as an evolutionarily conserved lncRNA plays a positive role in regulating proliferation and maintaining the undifferentiated status of early-stage hematopoietic cells. BMC Genomics. 2015; 16:676. doi: 10.1186/ s12864-015-1881-x.

83. van Asseldonk M, Schepens M, de Bruijn D, Janssen B, Merkx G, Geurts van Kessel A. Construction of a 350-kb sequence-ready 11q13 cosmid contig encompassing the markers D11S4933 and D11S546: mapping of 11 genes and 3 tumor-associated translocation breakpoints. Genomics. 2000; 66:35-42. doi: 10.1006/geno.2000.6194.

84. Tripathi V, Ellis JD, Shen Z, Song DY, Pan Q, Watt AT, Freier SM, Bennett CF, Sharma A, Bubulya PA, Blencowe BJ, Prasanth SG, Prasanth KV. The nuclear-retained noncoding RNA MALAT1 regulates alternative splicing by modulating SR splicing factor phosphorylation. Mol Cell. 2010; 39:925-38. doi: 10.1016/j.molcel.2010.08.011.

85. Xiao H, Tang K, Liu P, Chen K, Hu J, Zeng J, Xiao W, Yu G, Yao W, Zhou H, Li H, Pan Y, Li A, et al. LncRNA MALAT1 functions as a competing endogenous RNA to regulate ZEB2 expression by sponging miR-200s in clear cell. Oncotarget. 2015; 6:38005-15. doi: 10.18632/ oncotarget.5357.

86. Cai X, Cullen BR. The imprinted H19 noncoding RNA is a primary microRNA precursor. RNA. 2007; 13:313-6. doi: 10.1261/rna.351707.

87. Xu Z, Yang F, Wei D, Liu B, Chen C, Bao Y, Wu Z, Wu D, Tan H, Li J, Wang J, Liu J, Sun S, et al. Long non-coding RNA-SRLR elicits intrinsic sorafenib resistance via evoking IL-6/STAT3 axis in renal cell carcinoma. Oncogene. 2016 Nov 14. doi: 10.1038/onc.2016.356. [Epub ahead of print].

88. Qu L, Ding J, Chen C, Wu ZJ, Liu B, Gao Y, Chen W, Liu F, Sun W, Li XF, Wang X, Wang Y, Xu ZY, et al. ExosomeTransmitted lncARSR Promotes Sunitinib Resistance in Renal Cancer by Acting as a Competing Endogenous RNA. Cancer Cell. 2016; 29:653-68. doi: 10.1016/j. ccell.2016.03.004.

89. Qu L, Wu Z, Li Y, Xu Z, Liu B, Liu F, Bao Y, Wu D, Liu J, Wang A, Chu X, Sun Y, Chen C, et al. A feed-forward loop between lncARSR and YAP activity promotes the expansion of renal tumour-initiating cells. Nat Commun. 2016; 7:12692. doi: 10.1038/ncomms12692.

90. Zhai W, Sun Y, Jiang M, Wang M, Gasiewicz TA, Zheng J, Chang C. Differential regulation of LncRNASARCC suppresses VHL-mutant RCC cell proliferation yet promotes VHL-normal RCC cell proliferation via modulating androgen receptor/HIF-2 $\alpha / \mathrm{C}-\mathrm{MYC}$ axis under hypoxia. Oncogene. 2016; 35:4866-80. doi: 10.1038/ onc.2016.19.

91. Shi X, Xu Y, Zhang C, Feng L, Sun Z, Han J, Su F, Zhang Y, Li C, Li X. Subpathway-LNCE: Identify dysfunctional subpathways competitively regulated by lncRNAs through integrating lncRNA-mRNA expression profile and pathway topologies. Oncotarget. 2016; 7:69857-69870. doi: 10.18632/oncotarget.12005. 